\title{
ÜLKEMIZDE AB KATILIM ÖNCESİ MALİ YARDIM ARACI KIRSAL KALKINMA (IPARD) BİLEŞENI KAPSAMINDAKİ FONLARIN KULLANIMI AMACIYLA HAZIRLANAN PROJELERDE DANIŞMANLIK HIZZMETININ ROLÜ
}

\section{Dr. Halil KARAKURT*}

\begin{abstract}
ÖZ
$B u$ çalışmada, IPARD Programı altındaki fonların kullanılabirliği üzerine danışmanlık hizmetinin etkileri araştırılmıştır. AB Komisyonu tarafindan Ă̆ustos 2011'de Yetki Devri Kararının verilmesinden sonra, TKDK Mayıs 2012 tarihine kadar 6 proje çağrısı gerçekleştirirken, ilk üç çağrıda sözleşmeye bağlanan projeleri netleştirerek yayınlamıştır. İlk başvuruda 41 proje başvurusundan 4 adedi ile, ikinci çağrıda 207 projeden 58'i; üçüncü çağrıda 150 projeden 99 proje ile sözleşme imzalanırken, danışmanlık hizmetinin 3 çağrıda proje başvuru sayısı ve sözleşmeye bağlanan projelerdeki paylart sirastyla \% 85,3 ve \% 75; \% 67,6 ve \% 70,6; \% 70,7 ve \% 70,7 olarak belirlenmiştir. Sözleşmeye bağlanma oran kademeli olarak artarken, bazı problemlerden dolayı istenen düzeye ulaşamamıştır. Ayrıca, yürütülen iki farklı anketten elde edilen bazı sonuçlar arasındaki ilişkiler istatistiki olarak analiz edilmiş ve değerlendirilmiştir. Sonuçta, danışmanlık hizmetinin önemli oranda danışman firmalar (\% 59) tarafindan yürütüldüğü, sözleşmeye bağlanan projelerin önemli bölümünün danışman firmalar tarafindan hazırlandiğı belirlenmiştir (\% 92,7).
\end{abstract}

Anahtar Kelimeler: Kırsal Kalkınma, IPARD, Proje Danışmanlığı

JEL Sinıflandırması: JEL Classification: O13, Q01, R11

\section{THE ROLE OF CONSULTANCY SERVICE ON PROJECTS PREPARED FOR USING OF FUNDS UNDER THE RURAL DEVELOPMENT COMPONENT (IPARD) OF FINANCIAL INSTRUMENT FOR PRE-ACCESSION ASSISTANCE IN TURKEY}

\begin{abstract}
In this study, it is searched the impact of project consultancy services on utility of fund amount allocated under IPARD. After the CoM Decision taken by the EC in August 2011, the ARDSI was carried out 6 calls for application and issued the list of contracted projects for the first three calls for application by May 2012. 4 out of 41 applications for the first call, 58 out of 207 application for the second, 99 out of 150 application for the third call for application were contracted. The rate of counsultancy within project application number and number of contracted projects at the three call
\end{abstract}

\footnotetext{
*T.C. Başbakanlık Hazine Müsteşarlığı, Dış Ekonomik İlişkiler Genel Müdürlüğü, halil.karakurt@hazine.gov.tr
} 
for applications were determined as 85,3\% and 75\%; 67,6\% and 70,6\%; 70,7\% and 70,7\% respectively. Although the contracting rate has gradually increased, it is seen that this rate is not satisfied because of some problems. In addition, two different questionnaires were assessed to determine the role of project counsultancy services and also statistical analyses were performed between some parameters. As a result, counsultancy service was performed by counsultant firms ( 59 $\%)$. Also, it is seen that the most of contracted projects were prepared by the consultancy firms $(92,7$ $\%)$.

Key Words: Rural Development, IPARD, Project Consultancy

JEL Classification: O13, Q01, R11

\section{INTRODUCTION}

Agriculture is a sector which has a critical importance for Turkish economy (Ege, 2011). This arises from providing nutrients, producing raw material for industry, creating employment and its contribution to export (Yavuz, 2005).

The proportion of agriculture in Gross Domestic Product (GDP) is 8,2 \% in Turkey (TUIK, 2013); 1,5 \% in the EU (Kandemir, 2011; Anonymous, 2012a).

In spite of arising important developments for this sector lately, the situation at production and quality is low level compared with the developed countries like the EU (Uysal and Oktay, 2008). The agricultural supports at the national level have been implementing especially in the rural areas where agricultural activities are more intensive. These supports comprise direct income support (Kandemir, 2011) and also machinery and equipments support (Anonymous, 2012b) which can contribute to improvement of establishments.

In Turkey, There are international supports aside from national supports which contribute to be obtained the high level standards for agricultural activities in the rural areas.

Funds for pre-accession to EU have an important role within the international supports since the end of 2001 following Turkey gained the candidate status to the EU in Helsinki at the end of 1999 (Karakurt, 2012).

The EU claims some conditions both the member and the candidate countries in order to have more strong financial structure and constitute a common policy from the beginning of its foundation. The EU provides financial supports to these countries with its own sources as fulfillment of relevant conditions meet by the countries (Yıldız and Yardımcıoğlu, 2005).

The agricultural structure of Turkey differs significantly from the EU countries in terms of the agricultural population, establishment size, producer organizations, agricultural supports, institutional organization, using technology, productivity, plant and animal health, crop quality and standards. 
After Turkey has gained candidate status to the EU, the significant amendments have been happening due to harmonization to Common Agricultural Policy of the EU in the agriculture sector (Karluk, 2002a).

The agricultural supports provided to Turkey by the EU focus on the small and medium enterprises which are mostly located in rural areas. Thus, it aims that these enterprises which compose of the majority in Turkey can reach to the EU minimum standards (Karluk, 2002b).

For the use of these funds, the Decentralised Implementation System (DIS) has established both using the funds of pre-IPA period (before 2007 year) and IPA period (2007-2013) in Turkey and all the structures and actors have been specified.

The IPA funds consist of five components and Turkey benefits from all these components due to its candidate status. The instrument for pre-accession assistance for rural development (IPARD) which is fifth component of the IPA is implemented as two phases in 2007-2013 years. In the first phase, the Conferral of Management Power (CoM) was granted for 20 Provincial Coordination Unit (PCU) and 3 measures (101, 103 and 302) after the 5 audits carried out by the EC's auditors in 2011. For the second phase, the accreditation process was finalised in 2013 for 22 additional PCUs and 4 measures $(101,103,302$ and 501).

Extended Decentralised Implementation System (EDIS) has been introduced for IPARD aside from the DIS performed in first four components of IPA. In this system, all the responsibilities and practices concerning the management and using of IPA funds are handed over fully to the relevant authorities without ex-ante control of the Delegation of the EC in Turkey (Karakurt, 2012).

The identification of the authorised units, the limits of the allocated funds, the implementation regions, the conditions for benefitting, the supported sectors, the potential applicants, the conditions for the application and all the processes including before application and after implementation are defined in IPARD Programme.

In the scope of IPARD Programme, Agriculture and Rural Development Support Institution (ARDSI) can perform fund utilisation based on project. In this regard, the most important point is to benefit EU funds at the optimum level and to increase the level of agricultural enterprises to the EU standards which is one of the main aims of the IPARD Programme that will provide a sound potential to the rural area (Uzunpinar, 2008). For that purpose, the projects prepared under the relevant measures/sub-measures are submitted to the relevant Provincial Coordination Unit (one of 20 PCUs accredited in the first phase of the IPARD Programme) by the applicants. It is obligatory that the applicants prepare the project application package on the basis of the needs of the relevant measure/sub-measure in the scope of IPARD Programme. In this respect, the ARDSI publishes the informative documents which provides the required information about submitting projects for each measure/sub-measure under the Programme. 
The absorption rate of the IPARD funds allocated in 2007-2013 depends on submitting sufficient numbers and qualified project applications.

The publicity and training activates performed by the relevant authorities has the key role for receiving a sufficient number of project application within the framework of IPARD by providing more awareness on Programme which has intensive procedures in Turkey.

The publicity and training activities for the targeted groups have been performed by the relevant authorities for that purpose. The project consultants within the targeted groups have a crucial role especially during project preparation and implementation of IPARD Programme in Turkey.

Simply, the consultant is a person who performs independently and objectively a defined service. It is expected that the consultants have a sufficient knowledge and experience in terms of consultancy approach as well as become a specialist in his/her profession and also an experience on project implementation. The consultancy firm is a specialist organization for the defined work during the process of preparation, implementation or evaluation of a project (Çölaşan, 2000).

Project applicants demand the consultancy service from the specialists in his/her field. Even though getting of consultancy is described a procurement service, the consultancy services have been begun to be defined as a profession (Boyacı and Karaturhan, 2003; Koçak, 2011).

Questioning the information and documents regarding background as well as previous works and credibility in the surrounding during determination of the consultant are important for reaching to the aim of the project (Grzebik, 2005; Ahirkar et al., 2006).

The public and private institutions have been applying a way of consultant employment or hiring for many issues such as health, agriculture, highway improvement and traffic security, education project (Işsk, 2008; Koçak, 2011).

The consultants have to obtain the commercial identity by registering the professional chambers related with their activity fields since these are able to submit a service for IPARD Programme. Because, they have to issue invoices of service provided to beneficiaries ${ }^{1}$.

The cost of consultancy services, feasibility works, architectural and engineering services are accepted as eligible in IPARD Programme. The half of these costs (50\%) which is not exceeding 6000 Euros is committed to be paid as grant. In addition, the applicants can show $4 \%$ maximum of eligible project amount as the preparation cost of business plan ${ }^{2}$.

In this study, the impact of project consultancy service has been evaluated on usage of the fund allocated under Instrument for Pre-accession Assistance Rural Development Programme (IPARD), in

\footnotetext{
1 Instrument for Pre-accession Assistance Rural Development (IPARD) Programme (2007-2013)

2 Agreement between The Government of the Republic of Turkey and the EC on the Rules for Cooperation Concerning EU-Financial Assistance to the Republic of Turkey and the Implementation of the Assistance under Componenet V (IPARD) of the Instrument for PreAccession Assistance (IPA)
} 
other words, on the project application with adequate number and quality both the data obtained from the first three calls for application and two different questionnaires prepared.

\section{MATERIAL and METHOD}

\subsection{The Scope and Aim of Questionnaires}

In this study, the conditions of the project consultants and the applicants during the process of project preparation on IPARD Programme which the implementation period has begun approximately for 1 year, their opinion and recommendations (if any) are evaluated. For this purpose, two different questionnaires are prepared for both groups.

The both questionnaires prepared were transmitted randomly to the project consultants and applicant/beneficiaries through all the 42 PCUs which the first and second phases of IPARD Programme have been implemented. The total 156 questionnaires filled by project consultants and the total 140 questionnaires filled by project applicants/beneficiaries were received and the role of project consultancy has been evaluated.

\subsection{Data analysis}

All data in this study were obtained from the ARDSI. These data were assessed and also analysed by SPSS software. The statistical analyses of data in relation to two questionnaires were performed by using crosstab and correlation analysis.

\section{RESULTS}

\subsection{The Assessment on Project Consultancy Services with Some Data of the IPARD Programme}

After the CoM Power was granted by the EC, implementation period of IPARD Programme in Turkey has been implementing. In this study, the data obtained from the first three calls for application which their contract status becomes definite in May 2012 were assessed (see Appendix A, B, C; Fig.1).

The status of consultancy service during project preparation and afterwards has been analysed with the evaluation of the data received from the ARDSI. 


\section{Figure 1. Assessment of Project Consultancy by the Data of First Three Calls Received from the} ARDSI

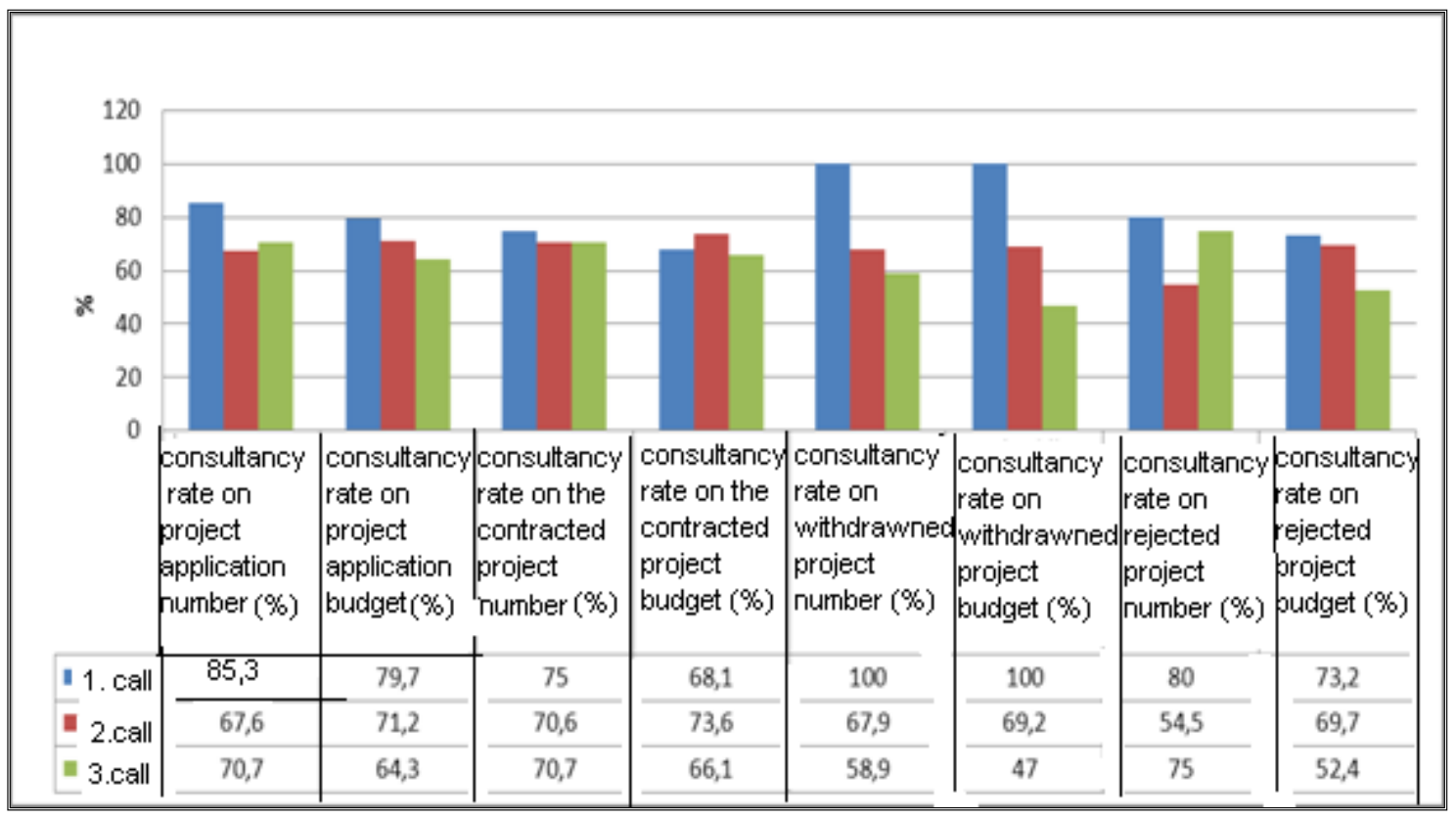

\subsection{Data of The First Calls of Application}

The ARDSI has launched the first call of application in 17 Provincial Coordination Units (PCUs) on July 1 of 2011. Totally, 41 project applications were submitted to the ARDSI within this period. But, 11 project applications were withdrawn by the applicants. The most project applications were submitted from the sub-measure of milk producing agricultural holdings (101-1). The usage rate of project consultancy service is determined as $85,5 \%$ in terms of number of project applications, 79,7 $\%$ in terms of total budget of project applications. In addition, 3 out of 4 contracted applications (75 $\%$ ) is prepared by consultancy service, its rate in total contracted amount is $68,1 \%$ as well. In the scope of this call for application, some project applications were withdrawn by the applicants and a significant part of those were rejected (26 applications) as a result of evaluations of the ARDSI (see Appendix A).

\subsection{Data of The Second Calls of Application}

ARDSI has launched the second calls for applications in 17 PCUs. Totally, 207 project applications were submitted to the ARDSI within this call for application. The usage rate of consultancy service were determined as $67,6 \%$ in terms of project application and 71,2\% in terms of total amount of projects. As a result of evaluations, 58 project applications were contracted and 41 of those were prepared by consultancy service $(70,6 \%)$ and its rate within contracted amount was 73,6 $\%$. In addition, 134 project applications were withdrawn by the applicants and 11 project applications were rejected by the ARDSI (see Appendix B).

\subsection{Data of Third Calls of Application}


ARDSI has launched the third calls for applications in 20 PCUs. Totally, 150 project applications were submitted to the ARDSI within this call for application. The usage rate of consultancy service were determined as $70,7 \%$ in terms of project application and $64,3 \%$ in terms of total amount of projects. As a result of evaluations, 99 project applications were contracted and 70 of those were prepared by consultancy service $(70,7 \%)$ and its rate within contracted amount was 66,1 $\%$. In addition, 12 project applications were rejected by the ARDSI (see Appendix C).

Within the first three calls, the main reason of rejection for administrative controls was that the missing documents in application package could have not been submitted in time for administrative controls, the reason of rejection for eligibility controls was that the offers could have not been met the technical specifications and not be submitted in appropriate format.

\section{Figure 2. The Distribution of Working Status of Project Consultants}

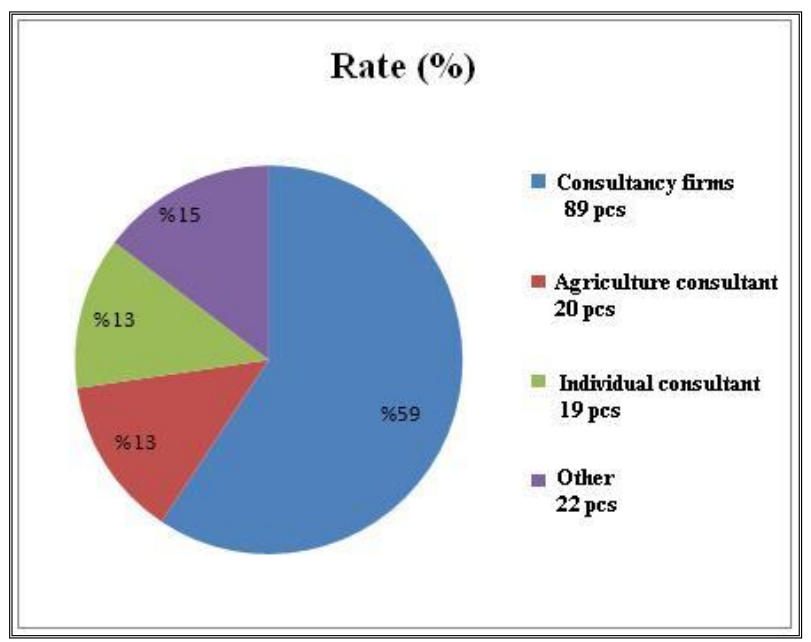

In the light of the data obtained from the questionnaire, important part of project consultancy service for IPARD Programme in Turkey has been fulfilled by the consultancy firms (59\%) (see Fig.2).

Table 1. The Relation Working, Technical Staff, Experience, Training Status and Contracting Rate

\begin{tabular}{|l|c|c|c|c|c|c|}
\hline $\begin{array}{l}\text { Consultancy } \\
\text { status }\end{array}$ & $\begin{array}{l}\text { Total } \\
\text { number }\end{array}$ & $\begin{array}{l}\text { Average } \\
\text { staff number }\end{array}$ & $\begin{array}{l}\text { Experience } \\
\text { (year) }\end{array}$ & $\begin{array}{l}\text { Ones with } \\
\text { general } \\
\text { trainings (\%) }\end{array}$ & $\begin{array}{l}\text { Ones with } \\
\text { IPARD } \\
\text { training (\%) }\end{array}$ & $\begin{array}{l}\text { Contracting } \\
\text { rate (\%) }\end{array}$ \\
\hline $\begin{array}{l}\text { Consultancy } \\
\text { firm }\end{array}$ & 78 & $4-5$ & 4 & 89,7 & 76,9 & 46,1 \\
\hline Individual & 21 & 1 & 3 & 80,9 & 61,9 & 4,8 \\
\hline $\begin{array}{l}\text { Agriculture } \\
\text { consultant }\end{array}$ & 16 & $1-2$ & 2 & 62,5 & 50,0 & 0 \\
\hline Other & 10 & 1 & 1 & 40,0 & 40,0 & 10,0 \\
\hline
\end{tabular}


It is observed that 78 out of $125(62,4 \%)$ consultants which replied the questionnaire have serviced as consultancy firm. Compared with the other service status, consultancy firms have adequate staff, experience and general and IPARD trainings on project preparation and also more contracting rate (see Table 1).

\subsection{The Statistical Analysis of the Questionnaires}

The Crosstab and correlation analysis have been used in order to determine the relations among some data obtained from the questionnaire. The results are shown in Table 2.

Table 2. The Relations between Consultancy Status and Contracting Rate

\begin{tabular}{|l|l|l|l|l|}
\hline \multicolumn{2}{|c|}{} & Contracting & Total \\
\hline Consultancy status & & Yes & No & 68 \\
\hline \multirow{3}{*}{ Consultancy firms } & Number & 38 & 30 & 78,2 \\
\cline { 2 - 5 } & $\%$ & 92,7 & 65,2 & 4 \\
\hline \multirow{2}{*}{ Agriculture consultant } & Number & 1 & 3 & 4,6 \\
\cline { 2 - 5 } & $\%$ & 2,4 & 6,5 & 10 \\
\hline \multirow{2}{*}{ Individual } & Number & 2 & 8 & 11,5 \\
\cline { 2 - 5 } & $\%$ & 4,9 & 17,4 & 5 \\
\hline \multirow{2}{*}{ Other } & Number & 0 & 5 & 87 \\
\cline { 2 - 6 } & $\%$ & 0 & 10,9 & 100 \\
\hline \multirow{2}{*}{ Total } & Number & 41 & 46 & \\
\cline { 2 - 6 } & $\%$ & 100 & 100 & \\
\hline
\end{tabular}

Table 3. The Importance Level of the Relations between Consultancy Status and Contracting Rate

\begin{tabular}{|l|l|l|l|}
\hline \multirow{2}{*}{} & \multicolumn{3}{|c|}{ Ki-Square Test } \\
\cline { 2 - 4 } & Value & SD & P \\
\hline $\begin{array}{l}\text { Pearson Ki- } \\
\text { Square }\end{array}$ & 10,288 & 3 & 0,016 \\
\hline
\end{tabular}

$\mathrm{P}<0,05$ significant, $\mathrm{P}>0,05$ Non significant

The contracted projects were significantly prepared by the consultancy firms $(92,7 \%)$ and the relation between consultancy status and contracting rate was statistically significant $(\mathrm{P}<0,05)$ (see Table 2 and 3).

Table 4. The Relation between Adoption of General Training and Contracting Rate

\begin{tabular}{|l|l|l|l|l|}
\hline \multicolumn{4}{|c|}{ Contracting } \\
\hline $\begin{array}{l}\text { Adoption of general project } \\
\text { trainings }\end{array}$ & & Yes & No & Total \\
\hline \multirow{3}{*}{ Yes } & Number & 37 & 35 & 72 \\
\cline { 2 - 5 } & $\%$ & 92,5 & 76,1 & 83,7 \\
\hline \multirow{3}{*}{ No } & Number & 3 & 11 & 14 \\
\cline { 2 - 5 } Total & $\%$ & 7,5 & 23,9 & 16,3 \\
\hline & Number & 40 & 46 & 86 \\
\cline { 2 - 6 } & $\%$ & 100 & 100 & 100 \\
\hline
\end{tabular}


Table 5. The Importance Level of the Relation between Adoption General Training and Contracting Rate

\begin{tabular}{|l|l|l|l|}
\hline \multirow{2}{*}{} & \multicolumn{3}{|c|}{ Ki-Square Test } \\
\cline { 2 - 4 } & Value & SD & $\mathrm{P}$ \\
\hline $\begin{array}{l}\text { Pearson Ki- } \\
\text { Square }\end{array}$ & 4,229 & 1 & 0,04 \\
\hline $\mathrm{P}<0,05$ significant, $\mathrm{P}>0,05$ Non significant
\end{tabular}

The relations between adoption of general training for project preparation and contracting rate was statistically significant $(\mathrm{P}<0,05)$. It is observed that the attendance to the general trainings about project process $(92,5 \%)$ can increase significantly the contracting rate (see Table 4 and 5).

Figure 3 and 4. The Usage Status and Selection Criteria of Consultancy Service by the Applicants
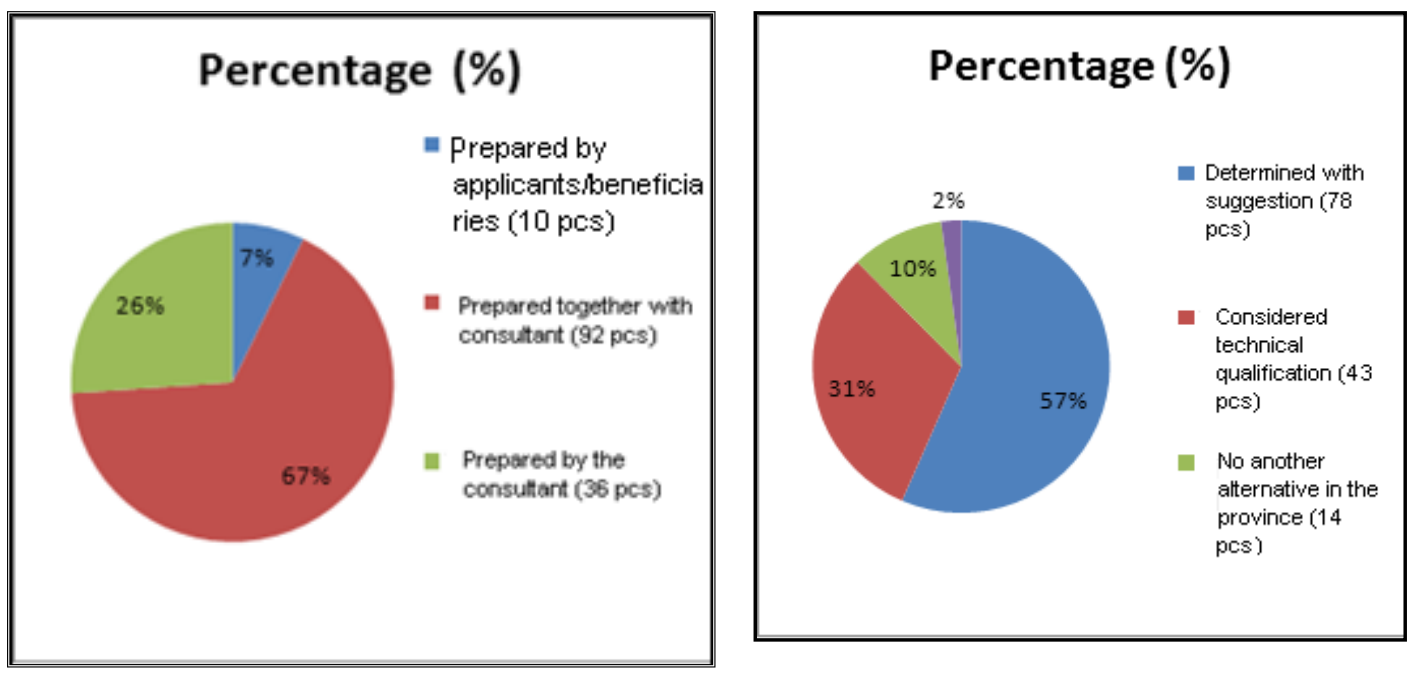

It is observed that projects within the questionnaire have been prepared together with consultants $(67 \%)$, by only the consultant (26\%), without consultant (7\%) (see Fig. 3). In addition, consultancy service within the questionnaire have been determined with suggestion (57\%), considered technical qualifications (31\%), no another alternative in the province $(10 \%)$ by the applicants and beneficiaries (see Fig.4).

Table 6. The Correlation between Using of Consultancy and Contracting Rate

\begin{tabular}{|l|l|l|l|l|}
\hline \multicolumn{2}{|c|}{ Contracting } \\
\hline Using of consultancy service & & Yes & No & Total \\
\hline \multirow{2}{*}{$\begin{array}{l}\text { Prepared by the } \\
\text { applicant/beneficiary completely }\end{array}$} & Number & 4 & 5 & 9 \\
\cline { 2 - 5 } & $\%$ & 10,8 & 5,4 & 6,9 \\
\hline \multirow{2}{*}{ Prepared by the consultants } & Number & 33 & 88 & 121 \\
\cline { 2 - 5 } & $\%$ & 89,2 & 94,6 & 93,1 \\
\hline \multirow{2}{*}{ Total } & Number & 37 & 93 & 130 \\
\cline { 2 - 5 } & $\%$ & 100 & 100 & 100 \\
\hline
\end{tabular}


Table 7. The importance level of the correlation between using consultancy and contracting rate

\begin{tabular}{|l|l|l|l|}
\hline \multirow{2}{*}{} & \multicolumn{3}{|c|}{ Ki-Square Test } \\
\cline { 2 - 4 } & Value & SD & P \\
\hline Pearson Ki-Square & 1,213 & 1 & 0,271 \\
\hline $\mathrm{P}<0,05$ significant, $\mathrm{P}>0,05$ Non significant
\end{tabular}

It is determined that most of the contracted projects have been prepared by the consultants. But, the relation between contracting and using of consultancy service is positive but statistically nonsignificant $(\mathrm{P}>0,05)$ (see Table 6 and 7$)$.

Spearmen correlation coefficient was also calculated in order to determine the correlation among some parameters obtained from the questionnaires. Spearmen correlation coefficient has the value between (-1) and (+1). The importance level of adverse relations among the variables increases as the value approaches to -1 and relations with parallel directions among the variables increases as the value approaches to +1 .

According to the data obtained, consultancy status and contracting rate has a positive and very significant relation $(\mathrm{r}=0,340 * *)$, consultancy status and adoption of general training has a positive and very significant relation $(\mathrm{r}=0,413 * *)$ (see Appendix D).

A positive and statistically significant $(r=0,179 *, P<0,05)$ relation has been determined between adoption of general and IPARD trainings (see Appendix E). It is thought that the applicants/beneficiaries attended to trainings on general project preparation have more awareness on IPARD Programme.

\section{DISCUSSION}

After the CoM Decision granted by the EC on August 2011, 6 calls for application have been carried out by the ARDSI. The data obtained from the first three calls for application which their contract status becomes definite in May 2012 were assessed. 4 out of 41 in first call, 58 out of 207 in second call, 99 out of 150 in third call were contracted. It is seen that the status of contracting increases gradually (see Appendix A; B; C).

Due to $n+3$ rule, the ARDSI had to spend the budget of 2007 and 2008 years the allocated till the end of 2011. In order to be spent the budget; the beneficiaries of contracted projects have to declare their expenditures immediately to the ARDSI after completion of projects. The ARDSI forced itself to take projects as much as possible. Therefore, the ARDSI published call for applications immediately and shortened the period of calls in the beginning of third quarter of 2011 after the CoM Decision. 
This time restriction caused to the high number of withdrawn and rejected applications during first two calls because most of project applications were prepared inattentively and quickly and then were submitted to the ARDSI. Moreover, the project applications could have not been prepared as requested because the IPARD Programme was implemented newly in Turkey and consequently both the applicants and consultants were inexperienced in that period. As a result of the reason mentioned above, some of projects were not submitted in time and many of projects were submitted with missing documents and information. Thus, the number of withdrawal and rejection were higher than expected (see Appendix A and B).

The number of withdrawal and rejection decreased significantly in third call for application. It is thought that the reason of this situation could be publicity activities increasing, awareness and knowledge of potential applicants and consultants on IPARD Programme (see Appendix C). In addition, the ARDSI prolonged the period between call for application and submission date in third call. These issues contributed positively on the process of project application by performed the applicant and consultants.

The results of both questionnaires were shown with figures and also Spearmen and Pearson coefficients were calculated in order to exhibit the correlation among some parameters. In the light of the data, the relation between consultancy status and adoption of general project trainings, contracting was statistically significant (see Table 2,3,4 and 5).

The rate of contracted projects increased significantly as more training on project preparation was adopted and projects were prepared by the consultants. The relation between contracting and using of consultancy service by the applicants is positive but statistically non-significant $(P>0,05)$ (see Table 6 and 7).

It is thought that the high number of withdrawal assessed as rejection in calls for application performed during preparation of both questionnaires could cause statistically non-significant relations among some parameters, although expected statistically significant.

Within the scope of both questionnaires, remarkable problems encountered, opinions and recommendations were taken into consideration. Similar issues were reflected from applicants, beneficiaries and also consultants.

These issues were the negative impression of all projects the rejected in conditional call performed before the CoM Decision on potential project applicants, excessive and exhaustive procedures implemented in Programme during and also after project application, non-realistic and outdated limits of minimum and maximum application capacities specified each measure/submeasure, difficulties encountered during receiving offers from suppliers, non-standardised consultancy service in Turkey, bureaucratic and financial problems during obtaining the official documents for 
application, financial problems due to absence of advance payment, lack of publicity and training activities especially in rural areas.

The project application and implementation in IPARD Programme require more seriousness due to its excessive control process and procedures. Despite all problems encountered, it is considered that the consultant and applicants adapted to IPARD implementation may contribute more efficiently on current national project culture provided that the significant problems are solved.

The IPARD Programme implemented in Turkey which is a candidate to the EU aims the agriculture standards in Turkey to raise the Community standards. The current agricultural system in Turkey has experienced some significant problems during IPARD Programme due to an adaptation period needed, difference between the agricultural standards of Turkey and EU.

It is concluded that the project consultancy service has an important role for preparation and implementation of projects. However, project consultancy standards in Turkey need to be improved and also adapted to new IPARD Programme. Thus, the number of qualified projects can be submitted. This situation could contribute significantly to reach to the targets of Programme and accordingly positive effect on fund absorption capacity.

\section{Acknowledgements}

I wish to thank National Authorising Officer's Office (NAO Office) under Undersecretariat of Turkish Treasury for helping to prepare the expert thesis which is the source of this manuscript. 


\section{REFERENCES}

Ahırkar, P., Singh, D., Sharda, S. (2006) "Project Report on Role of Project Management Consultant and Model Tender Document”. Government of India Ministry of Railways, 33.

Anonymous, (2012a) "World Bank Agriculture Values for GDP" (http://data.worldbank.org/indicator/NV.AGR.TOTL.ZS/countries).

Anonymous, 2012b. "Kırsal Kalkınma Yatırımlarının Desteklenmesi Programı Kapsamında Makine ve Ekipman Alımlarının Desteklenmesi Hakkında Tebliğ (No: 2013/27)" Gıda, Tarım ve Hayvancılık Bakanlı̆̆ı, Ankara.

Boyac1, M.,Karaturhan, B. (2003) "A Research on Agricultural Extension Activities on Ecological Farming” (in Turkish with English abstract). Ege Üniv. Ziraat Fak. Dergisi, 40 (3):113-120.

Çölaşan, R. (2000) “Tarımsal Proje ve Danışmanlik Hizmetleri”, Türkiye Ziraat Mühendisliği V. Teknik Kongresi, 2: 1127-1133.

Ege, H. (2011) “Tarım Sektörünün Ekonomideki Yeri ve Önemi”. Tarımsal Ekonomi ve Politika Geliştirme Enstitüsü, 7:1-4, Ankara.

Grzebik, B. (2005) "The Importance of Hiring a Consultant”, Grzebik Group, Church \& Worship Technology, www.gdgpro.com.

IPARD Programme, (2012) "Instrument for Pre-Accession Assistance Rural Development (IPARD) Programme (2007-2013)".

Işık, Y. (2008) “Avrupa Birliği Fonlarının Türkiye Ekonomisindeki Yeri”, 2. Ulusal İktisat Kongresi, İzmir.

Kandemir, O. (2011) “The Effect of Agricultural Support Policies upon Rural Development (in Turkish with English abstract). Ekonomi Bilimleri Dergisi, 3(1):103-113.

Karakurt, H. (2012) “The Role of Consultancy Firms on Projects Prepared for Using of Funds Under the Rural Development Component (IPARD) of Financial Instrument for Pre-Accession Assistance in Turkey" (in Turkish with English abstract). Uzmanlık Tezi, 108s. T.C Başbakanlık Hazine Müsteşarlığı, Dış Ekonomik İlişkiler Genel Müdürlüğü, Ankara.

Karluk, R. (2002a) “Türkiye Ekonomisi”, Betaş Yayınları, İstanbul.

Karluk, R. (2002b) “Avrupa Birliği ve Türkiye”, Betaş Yayınları, İstanbul.

Koçak, K., 2011. Danışmanlık hizmeti alımı işlerinde asgari işçilik uygulamaları (in Turkish). Mali Çözüm, 189-196. 
Sectoral Agreement, 2010/658 "Agreement between the Government of the Republic of Turkey and the EC on the Rules for Cooperation Concerning EU-Financial Assistance to the Republic of Turkey and the Implementation of the Assistance under Componenet V (IPARD) of the Instrument for Pre-Accession Assistance (IPA)".

TUiK, (2013) “Türkiye İstatistik Kurumu”, Ankara.www.tuik.gov.tr

Uysal, Ö.K., Oktay, E. (2008) “Comparison of Turkish and European Union Agricultural Sectors" (in Turkish with English abstract). 2. Ulusal İktisat Kongresi, İzmir.

Uzunpınar, A. (2008) "Katı1ım Öncesi AB Kırsal Kalkınma Politikası ve Türkiye'de Uygulanacak IPARD Programı Kapsaminda Proje Hazırlama, Değerlendirme ve Seçim Süreci”. Uzmanlık Tezi, T. C. Tarım ve Köyişleri Bakanlığı Dış İlişkiler ve Avrupa Topluluğu Koordinasyon Dairesi Başkanlığı Ankara.

Yavuz, F. (2005) “Türkiye'de Tarım”, Atatürk Üniversitesi Ziraat Fakültesi Tarım Ekonomisi Bölümü, Erzurum.

Y1ldız, H., Yardımcioğlu, F. (2005) "The European Union Fiscal Assistances to Turkey and Comparation with the Candidate Countries" (in Turkish with English abstract). C.Ü. İktisadi ve İdari Bilimler Dergisi, 6:75-104. 
Appendix A: Proportion of Consultancy Service in Number of Projects, Contracting, Withdrawn and Rejection Status within First Call for Application of IPARD

\begin{tabular}{|c|c|c|c|c|c|c|c|c|c|c|c|}
\hline Measure/Sub measure & 101-1 & 101-2 & 103-1 & 103-2 & 103-3 & 103-4 & 302-1 & $302-2$ & $302-3$ & $302-4$ & Total \\
\hline Number of project applicants & 12 & 11 & 6 & 4 & - & - & 1 & 5 & - & 2 & 41 \\
\hline $\begin{array}{l}\text { Total project budget } \\
\text { (TL) }\end{array}$ & 10.409 .976 & 12.878 .300 & 12.132 .693 & 4.680 .877 & - & - & 473.295 & 2.263 .680 & - & 496.800 & 43.335 .627 \\
\hline Number of projects prepared by consultants & 10 & 11 & 3 & 4 & - & - & 1 & 5 & - & 2 & 35 \\
\hline Budget of projects prepared by consultant (TL) & 7.092 .940 & 12.878 .300 & 7.122 .534 & 4.680 .877 & - & - & 473.295 & 2.263 .680 & - & 496.800 & 34.535 .136 \\
\hline Number of contracted projects & 1 & 1 & 1 & - & - & - & - & - & - & 1 & 4 \\
\hline $\begin{array}{l}\text { Budget of contracted projects } \\
\text { (TL) }\end{array}$ & 85.190 & 955.922 & $676.386,00$ & - & - & - & - & - & - & 404.587 & 2.122 .086 \\
\hline $\begin{array}{l}\text { Number of contracted projects prepared by } \\
\text { consultant }\end{array}$ & 1 & 1 & - & - & - & - & - & - & - & 1 & 3 \\
\hline $\begin{array}{l}\text { Budget of contracted projects prepared by } \\
\text { consultant (TL) }\end{array}$ & 85.190 & 955.922 & - & - & - & - & - & - & - & 404.587 & 1.445 .700 \\
\hline Number of withdrawn projects & - & 9 & - & - & - & - & - & 2 & - & - & 11 \\
\hline Budget of withdrawn projects (TL) & - & 11.691 .539 & - & - & - & - & - & 849.180 & - & - & 12.540 .719 \\
\hline $\begin{array}{l}\text { Number of withdrawn projects prepared by } \\
\text { consultant }\end{array}$ & - & 9 & - & - & - & - & - & 2 & - & - & 11 \\
\hline $\begin{array}{l}\text { Budget of withdrawn projects prepared by } \\
\text { consultant (TL) }\end{array}$ & - & 11.691 .539 & - & - & - & - & - & 849.180 & - & - & 12.540 .719 \\
\hline Number of rejected projects & 11 & 1 & 5 & 4 & - & - & 1 & 3 & - & 1 & 26 \\
\hline Budget of rejected projects (TL) & 10.247 .949 & 210.000 & 11.456 .307 & 4.680 .877 & $\overline{-}$ & $\overline{-}$ & 473.295 & 1.414 .500 & $\overline{-}$ & 76.922 & 28.559 .852 \\
\hline $\begin{array}{l}\text { Number of rejected projects prepared by } \\
\text { consultant }\end{array}$ & 9 & 1 & 3 & 4 & - & $\overline{-}$ & $\overline{-}$ & 3 & - & 1 & 21 \\
\hline $\begin{array}{l}\text { Budget of rejected projects prepared by } \\
\text { consultant (TL) }\end{array}$ & 7.391 .558 & 210.000 & 7.122 .537 & 4.680 .877 & - & - & - & 1.414 .500 & - & 76.922 & 20.896 .396 \\
\hline
\end{tabular}

Measure 101: Investments in agricultural holdings to restructure and to upgrade to community standards

Measure 103: Investments in processing and marketing of agricultural and fishery products to restructure those activities and upgrade them to community standard

Measure 302: Diversification and development of rural economic activities 
Appendix B: Proportion of Consultancy Service in Number of Projects, Contracting, Withdrawn and Rejection Status within Second Call for Application of IPARD

\begin{tabular}{|c|c|c|c|c|c|c|c|c|c|c|c|}
\hline Measure/Sub measure & $101-1$ & $101-2$ & $103-1$ & $103-2$ & $103-3$ & $103-4$ & $302-1$ & $302-2$ & $302-3$ & $302-4$ & Total \\
\hline Number of project applicants & 95 & 54 & 13 & 7 & - & 3 & 6 & 15 & 11 & 3 & 207 \\
\hline $\begin{array}{l}\text { Total project budget } \\
\text { (TL) }\end{array}$ & 137.563 .399 & 61.871 .482 & 41.835 .617 & 29.280 .202 & - & 8.178 .454 & 886.794 & 9.911 .555 & 8.659 .903 & 721.726 & 298.909 .135 \\
\hline Number of projects prepared by consultants & 65 & 42 & 8 & 4 & - & 3 & 4 & 8 & 5 & 1 & 140 \\
\hline $\begin{array}{l}\text { Budget of projects prepared by consultant } \\
\text { (TL) }\end{array}$ & 100.175 .895 & 48.829 .434 & 29.140 .880 & 17.821 .562 & - & 8.178 .454 & 820.705 & 2.682 .186 & 5.192 .269 & 97.700 & 212.939 .086 \\
\hline Number of contracted projects & 19 & 23 & 6 & 1 & - & 1 & - & 4 & 4 & - & 58 \\
\hline $\begin{array}{l}\text { Budget of contracted projects } \\
\text { (TL) }\end{array}$ & 25.993 .960 & 24.222 .191 & 31.516 .481 & 497.497 & - & 3.537 .000 & - & 1.839 .318 & 2.956 .966 & - & 90.563 .416 \\
\hline $\begin{array}{l}\text { Number of contracted projects prepared by } \\
\text { consultant }\end{array}$ & 13 & 17 & 5 & - & - & 1 & - & 2 & 3 & - & 41 \\
\hline $\begin{array}{l}\text { Budget of contracted projects prepared by } \\
\text { consultant (TL) }\end{array}$ & 16.938 .915 & 18.470 .339 & 24.708 .734 & - & - & 3.537 .000 & - & 660.318 & 2.349 .127 & - & 66.664 .435 \\
\hline Number of withdrawn projects & 68 & 27 & 5 & 5 & - & 2 & 6 & 11 & 6 & 3 & 134 \\
\hline Budget of withdrawn projects (TL) & 98.781 .014 & 32.720 .057 & 9.8112 .304 & 22.274 .360 & \begin{tabular}{|l}
- \\
\end{tabular} & 4.520 .167 & 886.794 & 7.988 .835 & 3.968 .666 & 721.726 & 182.774 .617 \\
\hline $\begin{array}{l}\text { Number of withdrawn projects prepared by } \\
\text { consultant }\end{array}$ & 48 & 23 & 3 & 3 & - & 2 & 4 & 6 & 1 & 1 & 91 \\
\hline $\begin{array}{l}\text { Budget of withdrawn projects prepared by } \\
\text { consultant (TL) }\end{array}$ & 74.092 .024 & 27.191 .010 & 5.435 .859 & 11.314 .670 & - & 4.520 .167 & 820.705 & 1.983 .605 & 1.122 .613 & 97.700 & 126.578 .355 \\
\hline Number of rejected projects & 5 & 3 & 1 & 1 & - & 1 & - & - & - & - & 11 \\
\hline Budget of rejected projects (TL) & 5.757 .772 & 3.017 .593 & 143.006 & 6.506 .892 & - & 1.034 .675 & - & - & - & - & 16.459 .940 \\
\hline $\begin{array}{l}\text { Number of rejected projects prepared by } \\
\text { consultant }\end{array}$ & 2 & 2 & - & 1 & - & 1 & - & - & - & - & 6 \\
\hline $\begin{array}{l}\text { Budget of rejected projects prepared by } \\
\text { consultant (TL) }\end{array}$ & 1.357 .57 & 2.572 .104 & - & 6.506 .892 & - & 1.034 .675 & - & - & - & - & 11.471 .246 \\
\hline
\end{tabular}
Measure 101: Investments in agricultural holdings to restructure and to upgrade to community standards

Measure 103: Investments in processing and marketing of agricultural and fishery products to restructure those activities and upgrade them to community standard

Measure 302: Diversification and development of rural economic activities 
Appendix C: Proportion of Consultancy Service in Number of Projects, Contracting, Withdrawn And Rejection Status within Third Call for Application of IPARD

\begin{tabular}{|c|c|c|c|c|c|c|c|c|c|c|c|}
\hline Measure/Sub measure & $101-1$ & $101-2$ & $103-1$ & $103-2$ & $103-3$ & $103-4$ & $302-1$ & $302-2$ & $302-3$ & $302-4$ & Total \\
\hline Number of project applicants & 69 & 41 & 10 & 3 & - & 3 & 5 & 15 & 2 & - & 150 \\
\hline $\begin{array}{l}\text { Total project budget } \\
\text { (TL) }\end{array}$ & 103.144 .325 & 53.378 .592 & 40.541 .476 & 16.838 .851 & - & 10.599 .469 & 993.160 & 7.508 .021 & 1.800 .921 & - & 238.190 .095 \\
\hline Number of projects prepared by consultants & 50 & 31 & 6 & 2 & - & 1 & 2 & 13 & 1 & - & 106 \\
\hline Budget of projects prepared by consultant (TL) & 75.943 .314 & 39.032 .147 & 16.835 .598 & 9.733 .791 & - & 3.579 .198 & 601.000 & 6.482 .733 & 993.690 & - & 153.201 .475 \\
\hline Number of contracted projects & 43 & 34 & 5 & 3 & - & 1 & 5 & 7 & 1 & - & 99 \\
\hline $\begin{array}{l}\text { Budget of contracted projects } \\
\text { (TL) }\end{array}$ & 64.560 .804 & 44.773 .853 & 21.577 .804 & 16.838 .8511 & - & 3.579 .198 & 993.160 & 3.987 .708 & 993.690 & - & 157.305 .072 \\
\hline Number of contracted projects prepared by consultant & 30 & 26 & 2 & 2 & - & 1 & 2 & 6 & 1 & - & 70 \\
\hline $\begin{array}{l}\text { Budget of contracted projects prepared by consultant } \\
\text { (TL) }\end{array}$ & 47.352 .425 & 32.236 .075 & 6.126 .726 & 9.733 .791 & - & 3.579 .198 & 601.000 & 3.387 .708 & 993.690 & - & 104.010 .616 \\
\hline Number of withdrawn projects & 20 & 4 & 3 & 1 & - & 2 & - & 8 & 1 & - & 39 \\
\hline Budget of withdrawn projects (TL) & 28.966 .330 & 5.430 .446 & 8.719 .559 & 2.785 .277 & - & 7.020 .270 & - & 3.594 .713 & 807.230 & - & 57.323 .829 \\
\hline Number of withdrawn projects prepared by consultant & 11 & 3 & 3 & - & - & - & - & 6 & - & - & 23 \\
\hline $\begin{array}{l}\text { Budget of withdrawn projects prepared by consultant } \\
\text { (TL) }\end{array}$ & 11.875 .365 & 3.790 .082 & 8.719 .559 & - & - & - & - & 2.569 .425 & - & - & 26.954 .433 \\
\hline Number of rejected projects & 6 & 3 & 2 & - & - & - & - & 1 & - & - & 12 \\
\hline Budget of rejected projects (TL) & 9.617 .190 & 3.174 .291 & 10.244 .112 & - & - & - & - & 525.600 & - & - & 23.561 .194 \\
\hline Number of rejected projects prepared by consultant & 5 & 2 & 1 & - & - & - & - & 1 & - & - & 9 \\
\hline $\begin{array}{l}\text { Budget of rejected projects prepared by consultant } \\
\text { (TL) }\end{array}$ & 7.656 .532 & 2.186 .391 & 1.989 .312 & - & - & - & - & 525.600 & - & - & 12.357 .836 \\
\hline
\end{tabular}

Measure 101: Investments in agricultural holdings to restructure and to upgrade to community standards

Measure 103: Investments in processing and marketing of agricultural and fishery products to restructure those activities and upgrade them to community standard

Measure 302: Diversification and development of rural economic activities 
Appendix D: The Correlation Status among some Parameters on Project Consultants.

\begin{tabular}{|c|c|c|c|c|c|c|c|c|}
\hline & & Contracting rate & $\begin{array}{l}\text { Consultancy } \\
\text { working status }\end{array}$ & $\begin{array}{l}\text { Number of } \\
\text { technical staff }\end{array}$ & $\begin{array}{l}\text { Experience status } \\
\text { (year) }\end{array}$ & $\begin{array}{l}\text { Adoption of } \\
\text { general training }\end{array}$ & $\begin{array}{l}\text { Experience on } \\
\text { national projects }\end{array}$ & $\begin{array}{l}\text { Adoption of } \\
\text { IPARD } \\
\text { trainings }\end{array}$ \\
\hline \multirow{3}{*}{$\begin{array}{l}\text { Consultancy } \\
\text { working status }\end{array}$} & \begin{tabular}{|l|}
$\begin{array}{l}\text { Spearmen } \\
\text { coefficient }\end{array}$ \\
\end{tabular} & $0,340 * *$ & 1 & & & & & \\
\hline & $P$ & 0,001 & - & & & & & \\
\hline & Number & 87 & 148 & & & & & \\
\hline \multirow{3}{*}{$\begin{array}{l}\text { Number of } \\
\text { technical staff }\end{array}$} & \begin{tabular}{|l|} 
Spearmen \\
coefficient
\end{tabular} & $-0,226$ & $-0,133$ & 1 & & & & \\
\hline & $\mathrm{P}$ & 0,053 & 0,180 & - & & & & \\
\hline & Number & 74 & 103 & 103 & & & & \\
\hline \multirow{3}{*}{$\begin{array}{l}\text { Experience status } \\
\text { (year) }\end{array}$} & \begin{tabular}{|l|}
$\begin{array}{l}\text { Spearmen } \\
\text { coefficient }\end{array}$ \\
\end{tabular} & $-0,237^{*}$ & $-0,131$ & $0,334 * *$ & 1 & & & \\
\hline & $\mathrm{P}$ & 0,032 & 0,148 & 0,001 & - & & & \\
\hline & Number & 82 & 121 & 103 & 124 & & & \\
\hline \multirow{3}{*}{$\begin{array}{l}\text { Adoption of } \\
\text { general training }\end{array}$} & $\begin{array}{l}\begin{array}{l}\text { Spearmen } \\
\text { coefficient }\end{array} \\
\end{array}$ & $0,222 *$ & $0,413 * *$ & $-0,194$ & $-0,346^{* *}$ & 1 & & \\
\hline & $\mathrm{P}$ & 0,040 & 0,000 & 0,051 & 0,000 & - & & \\
\hline & Number & 86 & 147 & 102 & 123 & 147 & & \\
\hline \multirow{3}{*}{$\begin{array}{l}\text { Experience on } \\
\text { national projects }\end{array}$} & $\begin{array}{l}\begin{array}{l}\text { Spearmen } \\
\text { coefficient }\end{array} \\
\end{array}$ & 0,138 & $0,459 * *$ & $-0,214^{*}$ & $-0,291 * *$ & $0,672 * *$ & 1 & \\
\hline & $\mathrm{P}$ & 0,206 & 0,000 & 0,030 & 0,001 & 0,000 & - & \\
\hline & Number & 86 & 144 & 103 & 123 & 143 & 144 & \\
\hline \multirow{3}{*}{$\begin{array}{l}\text { Adoption of } \\
\text { IPARD trainings }\end{array}$} & $\begin{array}{l}\begin{array}{l}\text { Spearmen } \\
\text { coefficient }\end{array} \\
\end{array}$ & 0,063 & 0,204* & $-0,067$ & $-0,286 * *$ & $0,336 * *$ & $0,379 * *$ & 1 \\
\hline & $P$ & 0,565 & 0,014 & 0,503 & 0,001 & 0,000 & 0,000 & - \\
\hline & Number & 85 & 144 & 101 & 121 & 143 & 140 & 144 \\
\hline \multirow{3}{*}{$\begin{array}{l}\text { External technical } \\
\text { support }\end{array}$} & $\begin{array}{l}\text { Spearmen } \\
\text { coefficient }\end{array}$ & $-0,034$ & $-0,103$ & 0,131 & 0,032 & $0,243^{*}$ & 0,002 & $-0,028$ \\
\hline & $\mathrm{P}$ & 0,755 & 0,341 & 0,264 & \begin{tabular}{|l|l|}
0,777 \\
\end{tabular} & 0,024 & \begin{tabular}{|l|}
0,983 \\
\end{tabular} & 0,797 \\
\hline & Number & 86 & 87 & 74 & 82 & 86 & 86 & 85 \\
\hline
\end{tabular}

$\mathrm{P}<0,01$ Very significant, $\mathrm{P}<0,05$ Significant; $\mathrm{P}>0,05$ Non significant 
Appendix B: The Correlation among some Parameters on Project Applicants/Beneficiaries.

\begin{tabular}{|c|c|c|c|c|}
\hline & & $\begin{array}{l}\text { Adoption of general } \\
\text { training }\end{array}$ & $\begin{array}{l}\text { Adoption of IPARD } \\
\text { training }\end{array}$ & $\begin{array}{l}\text { Using of consultancy } \\
\text { service }\end{array}$ \\
\hline \multirow{3}{*}{$\begin{array}{l}\text { Adoption of } \\
\text { IPARD training }\end{array}$} & Spearmen coefficient & $0,179 *$ & 1 & \\
\hline & $\mathrm{P}$ & 0,049 & - & \\
\hline & Number & 121 & 122 & \\
\hline \multirow{3}{*}{$\begin{array}{l}\text { Using of } \\
\text { consultancy } \\
\text { service }\end{array}$} & Spearmen coefficient & $-0,101$ & $-0,013$ & 1 \\
\hline & $\mathrm{P}$ & 0,250 & 0,887 & - \\
\hline & Number & 131 & 122 & 132 \\
\hline \multirow{3}{*}{ Contracting } & Spearmen coefficient & 0,144 & $-0,060$ & 0,097 \\
\hline & $\mathrm{P}$ & 0,103 & 0,516 & 0,274 \\
\hline & Number & 129 & 120 & 130 \\
\hline
\end{tabular}

$\mathrm{P}<0,05$ significant, $\mathrm{P}>0,05$ Non significant 